\title{
Identification of physiological analysis parameters associated with coffee beverage quality
}

\author{
Identificação de parâmetros de análise fisiológica associados à qualidade da bebida de café
}

\author{
Marcella Nunes de Freitas ${ }^{1 *}(\mathbb{D})$, Sttela Dellyzete Veiga Franco da Rosa ${ }^{(D)}$, Cristiane Carvalho Pereira $^{1}$ (D), \\ Marcelo Ribeiro Malta ${ }^{3}$ (D) , Carlos Tadeu dos Santos Dias ${ }^{4}$ (iD
}

\author{
'Universidade Federal de Lavras/UFLA, Departamento de Agricultura, Lavras, MG, Brasil \\ ${ }^{2}$ Empresa Brasileira de Pesquisa Agropecuária/Embrapa, Embrapa Café, Lavras, MG, Brasil \\ ${ }^{3}$ Empresa de Pesquisa Agropecuária de Minas Gerais/EPAMIG, Lavras, MG, Brasil \\ ${ }^{4}$ Universidade de São Paulo/USP, Escola Superior de Agricultura Luiz de Queiroz/ESALQ, Departamento de Ciências Exatas, Piracicaba, SP, Brasil \\ *Corresponding author: cellanunes@yahoo.com.br \\ Received in December 18, 2019 and approved in April 22, 2020
}

\begin{abstract}
The demand for high-quality coffee among consumers has generated a great deal of interest among producers in serving this market. Parameters for physiological analyses that can be associated with aspects of sensory analyses of coffee can ensure more reliable results for coffee quality assessments. The aim of this study was to investigate the potential of physiological analyses in determining coffee quality through multivariate analysis. Several samples from coffee bean/seed lots were placed in cold storage at $10^{\circ} \mathrm{C}$, after which the sensory quality, physiological quality, and chemical characteristics of the beans were evaluated before storage and after three and six months of storage. The variables of physiological quality in the coffee beans were correlated with sensory analysis parameters. The viability of coffee embryos revealed by the tetrazolium test results were positively correlated with the final sensory analysis score. There was a correlation of root dry matter, hypocotyl dry matter, potassium leaching, and electrical conductivity with the sensory attributes that comprise the final sensory analysis score for the coffee beans. Variation in the final sensory analysis score was explained up to $97.14 \%$ by the variables radical emergence $\left(r^{2}=\right.$ $2.27 \%)$, strong normal seedlings, $\left(r^{2}=0.56 \%\right)$, seedlings with expanded cotyledonary leaves $\left(r^{2}=0.53 \%\right)$, tetrazolium test results $\left(r^{2}=91.54 \%\right)$, and potassium leaching $\left(r^{2}=2.24 \%\right)$. More studies are required to enable the use of physiological analyses to complement sensory analysis.
\end{abstract}

Index terms: Coffea arabica L.; sensory analysis; physiological tests; variable selection; canonical correlation.

\begin{abstract}
RESUMO
A demanda por cafés com alta qualidade pelos consumidores tem gerado um grande interesse dos produtores em atender esse mercado. Análises fisiológicas que podem ser associadas com a análise sensorial do café podem garantir resultados mais confiáveis para a avaliação da qualidade do café. Objetivou-se com o estudo investigar o potencial de utilização das análises fisiológicas na determinação da qualidade do café, por meio da aplicação de análises multivariadas. Lotes de grãos de café foram colocados sob armazenamento em câmara a $10^{\circ} \mathrm{C}$, e então foram realizadas avaliações da qualidade sensorial e fisiológica e das características químicas dos grãos antes do armazenamento e após três e seis meses de armazenamento. As variáveis de qualidade fisiológica dos grãos de café foram correlacionadas com a análise sensorial da bebida. A viabilidade dos embriões de café analisada pelo teste de tetrazólio foi positivamente correlacionada com a nota final da análise sensorial. Há correlação da matéria seca das raízes, matéria seca do hipocótilo, lixiviação de potássio e condutividade elétrica com os atributos sensoriais que compõem a nota final da análise sensorial dos grãos de café. 97,14\% da variação da nota final da análise sensorial foi explicada pelas variáveis de emergência radicular $\left(r^{2}=2.27 \%\right)$, plântulas normais fortes $\left(r^{2}=0.56 \%\right)$, plântulas com folhas cotiledonares expandidas $\left(r^{2}=0.53 \%\right)$, teste de tetrazólio $\left(r^{2}=91.54 \%\right)$ e lixiviação de potássio $\left(r^{2}=2.24 \%\right)$. Mais estudos são necessários para permitir o uso das análises fisiológicas para complementar a análise sensorial da bebida.
\end{abstract}

Termos para indexação: Coffea arabica L.; análise sensorial; testes fisiológicos; seleção de variáveis; correlação canônica.

\section{INTRODUCTION}

"Quality" is the term most often used to add market value to commodities such as coffee. In the case of coffee beans, quality is the result of production factors that are linked to aspects of the chemical composition of green coffee beans or roasted beans for characteristics of the final beverage, which are determined by sensory analysis and chemical analysis (Borém, 2008; Oliveira et al., 2013). Changes in the physical-chemical composition of coffee beans that lead to losses in sensory quality are 
evaluated by sensory analysis and analysis of chemical composition, which includes sugar concentrations, total titratable acidity, presence of soluble solids, and other factors (Borém, 2008).

Coffees are classified according to a flavor and aroma scale that determines beverage quality, and this is evaluated by the cupping method, i.e., sensory analysis (Lingle, 2011). Although this method is widely used for evaluating coffee beverage quality for commercial purposes, it involves a set of techniques created to evaluate a product through the perceptions, sensations, and reactions of the evaluator, resulting in approval or rejection (Della Lucia; Minim; Carneiro, 2006); this method might not provide consistent results since these are subjective data that depend on various factors, most notably, the evaluator (Borràs et al., 2015).

Differences in flavor intensity and mouthfeel attributes of coffee samples depend on the brewing method used to prepare them. Thus, using only one method when conducting sensory or quality testing can be an aspect that limits the information gathered in a sensory study (Sanchez; Chambers, 2015). Pramudya and Seo (2018) showed that both emotional responses to and the sensory attributes of coffee beverages can vary with sampling temperature. These aspects make sensory analysis vulnerable to subjectivity, as mentioned by Njoman et al. (2017).

Furthermore, the complexity of sensory analysis increases because beverage quality is related to many variables. Chambers IV et al. (2016) evaluated a sensory lexicon for determining descriptive differences in brewed coffee resulting from modifications in breeding, cultivation, processing, storage, and brewing. For aroma and flavor alone, 19 and 12 attributes were added, respectively. According to Di Donfrancesco, Gutierrez and Chambers IV (2014), the cupping method and sensory descriptive methods provide different information that cannot be used as an alternative to each other when describing coffee products. Both methods may be used synergistically to evaluate coffee samples due to the complexity of coffee quality evaluation and to increase understanding.

An analysis of seed physiological quality occurs through testing, with the aim of evaluating possible changes in the biochemical system of seeds that lead to losses in germination potential and/or changes in the cell membrane repair system (Marcos-Filho, 2015). How far physiological quality has been reduced can be confirmed by various tests; germination, radicle emergence, tetrazolium, electrical conductivity, and potassium leaching tests are common.

The results of these studies have shown a strong relationship between the sensory quality and the physiological quality of coffee beans (Borém et al., 2013a; Malta; Pereira; Chagas, 2005; Taveira et al., 2012; 2015). This indicates that production conditions, postharvest operations (such as the selection of ripe fruit, processing, and drying), and storage conditions will affect both the sensory quality of coffee beans and their physiological quality. From this, it follows that physiological analyses used for evaluating coffee seed quality are promising tools for evaluating the quality of coffee beans used for beverages (Abreu et al., 2017; Borém et al., 2013b; Taveira et al., 2012; 2015).

Studies have emphasized the relationship between the sensory quality and the physiological quality of coffee beans, and methods of evaluating the two have been used together to determine coffee quality (Clemente et al., 2015; Oliveira et al., 2013). Oliveira et al. (2013; 2018) and Taveira et al. (2015) related sensory analysis to germination, electrical conductivity, and potassium leaching to assess the best drying method for wet- and dryprocessed coffee beans. The importance of a physiological analysis in the determination of coffee beverage quality has been well established. However, no studies in the literature have sought to directly correlate aspects of sensory analyses with those of physiological analyses to demonstrate the degree of association between the two methods of evaluating quality.

Multivariate statistical analyses are methods that advance the evaluation of the quality of food and beverage products (Borràs et al., 2015). The analyses of variable selection are clustered according to their correlation with the dependent variable. In a canonical correlation, the main objective is to identify and quantify the linear relations between two sets of multiple variables, whether metrical or not. Using this multivariate statistical procedure, the relations between two sets of variables ( $\mathrm{X}$ and $\mathrm{Y}$ ) can be examined (Johnson; Wichern, 2002). In a cluster analysis, the values of the variables are used to place the objects in classes so that similar objects are in the same class and dissimilar objects are in different classes (Manly, 2008).

The identification of simple and fast methods that can complement the evaluation of coffee quality (sensory analysis) and that can be reproduced in a routine manner in a company is highly desirable (Alves; Dias; Benassi, 2006; Farah et al., 2006; Franca; Mendonça; Oliveira, 2005; Ribeiro; Ferreira; Salva, 2011). Reflecting the growing interest in analyses that contribute to the determination of coffee quality and the possible relation that physiological quality may have with sensory quality, our aim in this study was to use multivariate analysis to identify physiological analyses that show potential for the evaluation of coffee beverage quality. 


\section{MATERIAL AND METHODS}

\section{Coffee samples}

We used 10 lots of coffee (Coffea arabica L.) beans from the municipality of Varginha, Minas Gerais. Samples were obtained from the Fundação Procafé experimental station. Beans from lots 1, 2, and 3 were processed naturally (without the removal of pulp from seeds before drying); beans from lots 4,5 , and 6 were processed through fermentation (wet processed); and beans from lots 7, 8, and 9 were demucilaged mechanically (mechanical removal of pulp and mucilage before drying). The materials from lots 1,4 , and 7 were then dried in the sun, those from lots 2,5 , and 8 were dried in the shade, and those from lots 3 , 6 , and 9 were dried in a dryer at $30^{\circ} \mathrm{C}$.

Drying and processing were carried out in different ways to obtain samples with sensory quality contrasts in 9 lots, as described above. Lot 10, consisting of coffee beans of lower sensory quality, was added. After hulling or cleaning, the beans of each lot were placed in plastic packaging and then in cold storage regulated to $10^{\circ} \mathrm{C}$ and a relative humidity of $45 \% \pm 1 \%$. They were evaluated over a period of six months. For each storage period evaluated, i.e., at the beginning of storage and at three and six months of storage, the moisture content of samples from 10 lots of coffee beans was determined (International Organization for Standardization - ISO, 2003). Moisture content was determined in two replications. Additionally, during this time, sensory and physiological evaluations of the coffee beans were performed, and at 6 months, chemical evaluations were carried out.

\section{Sensory analysis}

One hundred grams of each sample was roasted within $24 \mathrm{~h}$ prior to the coffee sensory analysis, or "cupping." The roasting level was determined visually, using a color classification system of standardized color discs. The coffee beans were selected, excluding defective beans, to proceed to a medium light roast. The beans were roasted to 65 points on the Agtron color scale for the whole bean, with a tolerance of \pm 1 point (Lingle, 2011). After roasting, samples were selected once more, and beans with an off color that differed from the standard sample color were eliminated. This process allowed for the minimization of possible interference from the roasting process.

The sensory analysis was performed by two certified specialty coffee cuppers (SCAA-certified cuppers). The SCAA sensory analysis protocol was used according to the methodology proposed by Lingle (2011) for sensory evaluation of specialty coffees. They assigned scores from 0 to 10 for the attributes of fragrance/aroma, uniformity, presence of defects, sweetness, flavor, acidity, body, aftertaste, balance, and overall experience. This last aspect constitutes the overall impression (the taste experience of the individual evaluator, his/her personal appraisal). In each evaluation, five coffee samples representing each lot were cupped.

The final score was calculated by adding up the individual scores given for each of the primary attributes, and then defects, when present in the sample, were subtracted to arrive at the final score (Lingle, 2011). Table 1 shows the final score of the coffee bean lots used in this study during each storage period.

\section{Physiological analyses}

The germination test consisted of 50 coffee seeds in a roll of paper moistened with water at 2.5 times the weight of the paper, which was then maintained at a temperature of $30^{\circ} \mathrm{C}$. Four replications were performed. On the fifteenth day of the test, radicle emergence was evaluated by counting the seedlings with radicles of at least one millimeter in length, and the results were expressed as percentages. Seedlings were evaluated thirty days after beginning the test, and normal seedlings were determined according to the descriptions in the Rules for Seed Analysis ("Regras para Análise de Sementes") (Brasil, 2009). Normal seedlings were further classified as strong normal seedlings when they had hypocotyls with a length greater than or equal to $3 \mathrm{~cm}$, measured with a millimeter ruler, and were classified as weak normal seedlings when hypocotyls were shorter than $3 \mathrm{~cm}$.

After the germination test at thirty days, the normal seedlings were kept in the germination paper rolls for fifteen more days, at which time the seedlings that had expanded cotyledonary leaves were counted, and this result was called seedlings with expanded cotyledonary leaves. The roots and the shoots were separated into normal seedlings and weighed separately after drying in a forced air circulation oven at $60{ }^{\circ} \mathrm{C}$ until reaching a constant weight and obtaining root and hypocotyl dry matter; the results were expressed in grams per seedling.

Seed viability was determined by the tetrazolium test, with four replications of 25 coffee seeds for each lot. After soaking the seeds in water as described in Clemente et al. (2011), the embryos were extracted and soaked in $0.5 \%$ tetrazolium solution in dark colored bottles, which were kept at a temperature of $30{ }^{\circ} \mathrm{C}$ for three hours and classified as viable or inviable according to the location and extent of the damage. 
Table 1: Final score of the coffee bean lots during each storage period.

\begin{tabular}{cccc}
\hline Lot - Processing / coffee bean drying method & \multicolumn{3}{c}{ Months ${ }^{1}$} \\
\cline { 2 - 4 } & 0 & 3 & 6 \\
\hline L1 - Processed naturally / dried in the sun & 80.75 & 81.25 & 75.75 \\
L2 - Processed naturally / dried in the shade & 80.25 & 80.50 & 83.75 \\
L3 - Processed naturally / mechanical dryer at 30 ${ }^{\circ} \mathrm{C}$ & 77.50 & 80.25 & 79.00 \\
L4 - Fermentation / dried in the sun & 75.75 & 79.00 & 82.25 \\
L5 - Fermentation / dried in the shade & 82.75 & 80.50 & 80.25 \\
L6 - Fermentation / mechanical dryer at 30 ${ }^{\circ} \mathrm{C}$ & 82.50 & 81.50 & 81.00 \\
L7 - Demucilaged mechanically / dried in the sun & 78.50 & 82.50 & 81.50 \\
L8 - Demucilaged mechanically / dried in the shade & 81.25 & 83.50 & 81.75 \\
L9 - Demucilaged mechanically / mechanical dryer at 30 ${ }^{\circ} \mathrm{C}$ & 81.25 & 81.50 & 83.00 \\
L10 - Coffee beans of lower sensory quality & 54.00 & 52.75 & 56.00 \\
\hline
\end{tabular}

${ }^{1}$ Average values obtained from analyses by two certified specialty coffee cuppers (SCAA-certified cuppers).

Electrical conductivity was determined using four replications of 50 seeds from each lot, which were weighed, immersed in $75 \mathrm{~mL}$ of deionized water in $180 \mathrm{~mL}$ plastic cups, and kept in BOD at a temperature of $25^{\circ} \mathrm{C}$ for five hours. Measurements of electrical conductivity were taken in a DIGIMED CD-20 apparatus, and the results were expressed in $\mu \mathrm{S} \mathrm{cm}^{-1} \mathrm{~g}^{-1}$ of seeds. Aliquots of the residue were placed in glass containers so the amount of potassium leached could be determined using a DIGIMED NK-2002 flame photometer; the results of potassium leaching were expressed in $\mathrm{mg} \mathrm{kg}^{-1}$.

\section{Chemical analyses}

Total sugars, reducing sugars, and nonreducing sugars were extracted by the Lane-Eynon method and determined by the Somogy technique (Association of Official Analytical Chemistry - AOAC, 1990). Total titratable acidity was determined by titration with $0.1 \mathrm{~N}$ $\mathrm{NaOH}$, adapting the methodology cited by the AOAC (1990). Soluble solids were determined according to the AOAC (1990). Ether extract was determined in a Soxhlet apparatus, Tecnal brand, according to the standards of the AOAC (1990). The data were expressed in dry matter based on the moisture percentage. The chemical analysis was performed with four replications.

\section{Statistical analysis}

A completely randomized design was used in the analyses. Before proceeding with the multivariate analysis, normality and homoscedasticity tests were performed, and the need for transformation of the variables was verified. Analyses of stepwise variable selection, canonical correlation, and clustering among sensory, physiological, and chemical variables were used for multivariate statistics using the computational system developed by the SAS Institute Inc. (2010). The mean values of the results of the physiological, sensory, and chemical evaluations of each lot of coffee beans were calculated and transformed to zero mean and unit variance. This transformation was made to avoid overestimating or underestimating the weight of a variable studied in the final result due to measurement scale differences.

Two analyses of variable selection were performed. In the first, the evaluations made in the first and second time periods (at zero and three months) were considered, with the attributes determined in the sensory analysis (fragrance/aroma, uniformity, presence of defects, sweetness, flavor, acidity, body, aftertaste, balance, overall and final score) as the dependent variables. The second analysis of variable selection was made considering only the third period of evaluation (at six months) and had attributes from chemical analyses (total sugars, reducing sugars, nonreducing sugars, soluble solids, ether extract, and titratable acidity) as the dependent variables. The independent variables for the two analyses of variable selection were those in the physiological analyses (germination, radicle emergence, strong and weak normal seedlings, seedlings with expanded cotyledonary leaves, root and hypocotyl dry matter, tetrazolium test, electrical conductivity, and potassium leaching).

The last model of variable selection for each dependent variable was presented, and the independent 
variables within each model were classified by their level of contribution by the $\mathrm{F}$ test and partial and total correlation coefficients. A probability of 0.05 was necessary to include a variable in the model and a significance factor of 0.001 was required to remove it from the model.

For the canonical correlation analysis, the physiological tests were first clustered in two groups. The first corresponds to the physiological characteristics determined during the germination test, including radicle emergence, germination, strong and weak normal seedlings, seedlings with expanded cotyledonary leaves, and root and hypocotyl dry matter. The second group refers to the physiological tests with biochemical principles, which include the tetrazolium, electrical conductivity, and potassium leaching tests. These two groups of physiological analysis aspects were related to the attributes evaluated in the sensory analysis and to chemical analysis variables. The pairs of canonical correlations whose significance values $(\mathrm{P})$ were less than or equal to $5 \%$ were considered.

The canonical coefficients of each variable were multiplied by the mean obtained for the same variable within each lot of coffee beans evaluated, and from these results, the values of "V1" plotted on the abscissa axis were obtained. This corresponds to the sum total of the coefficients of the physiological tests determined during the germination test or of the physiological tests with biochemical principles. The "W1" values were plotted on the ordinate axis, which include the sum total of the coefficients obtained from the evaluations of the sensory or chemical analysis of the coffee beans.

For the hierarchical cluster analysis, the Euclidean distance of the results of the sensory, physiological, and chemical analyses of each lot of coffee beans and time of storage $\left(d=\sqrt{\sum_{i=1}^{n}(p i-q i)^{2}}\right)$ were considered, in which pi and qi are points of each parameter analyzed in an n-dimensional Euclidean space. As a manner of connection, the unweighted pair group method with arithmetic mean (UPGMA), which uses the mean distance as a measure of similarity, was carried out with the set of normalized data (Manly, 2008). From the results, two dendrograms were created - the first was from the average linkage between the results of the sensory and physiological analyses of the lots of coffee beans in the first two periods of evaluation, and the second dendrogram was constructed from the average linkage among the results of the sensory, physiological, and chemical analyses of the lots of coffee beans evaluated in the third time period. The shorter the distance between the clusters, the greater the similarity among the variables.

\section{RESULTS AND DISCUSSION}

The results of the moisture content of the coffee beans throughout the storage period showed a small increase in the moisture of the beans in all the lots evaluated. However, this change was not able to affect the results of the physiological, chemical, and sensory tests because the largest difference was $1.42 \%$ for lot 2 between the first time period and at 6 months (Table 2). Evaluation of seed moisture content is important when lots are compared, since large variations can compromise the interpretation of results obtained in vigor tests (Tekrony, 2003).

Table 2: Moisture content of Coffea arabica L. beans during the storage period.

\begin{tabular}{crcr}
\hline \multirow{2}{*}{ Lot } & \multicolumn{3}{c}{ Storage period } \\
\cline { 2 - 4 } & $0 \mathrm{~m}$ & $3 \mathrm{~m}$ & $6 \mathrm{~m}$ \\
\hline 1 & ---10.69 & 11.90 & 11.34 \\
2 & 10.86 & 12.11 & 12.28 \\
3 & 11.27 & 12.17 & 11.48 \\
4 & 11.62 & 12.43 & 11.99 \\
5 & 12.03 & 12.61 & 12.39 \\
6 & 9.89 & 10.23 & 10.27 \\
7 & 9.06 & 9.83 & 9.81 \\
8 & 13.11 & 14.23 & 13.58 \\
9 & 9.76 & 10.73 & 10.60 \\
10 & 10.02 & 11.03 & 10.72 \\
\hline
\end{tabular}

The first analysis of variable selection, considering the variables of the physiological tests, by observing the coefficients of total determination of each dependent sensory variable, showed that the sensory aspects were almost fully explained by the results of the physiological analyses. Only for the aroma aspect, the physiological variable of radicle emergence selected to explain this trait constituted an equation that corresponded to the lowest percentage of response variation of the lots, at $49.75 \%$ (Table 3).

The independent physiological variables germination, root dry matter, and hypocotyl dry matter were not included in any of the regression models of the variable selection analysis. In contrast, the analyses performed during the germination test, such as the evaluation of radicle emergence of the seedlings and of strong normal seedlings, which were included in 5 and 6 
equations of the dependent variables, respectively, were of great importance for explaining the sensory quality of the coffee beans (Table 3). This response shows that for both physiological analysis, which considers aspects related to seed quality, and sensory analysis, the germination test is an important method for evaluating the quality of coffee beans.

The tetrazolium test also showed great importance in explaining the sensory variation of the lots, and it was inserted in 9 of the 11 equations of the dependent variables analyzed, with high coefficients of partial determination, such as $91.54 \%$ for the final sensory analysis score.

The variation of the final sensory analysis score is formed by totaling the values for all the sensory attributes and subtracting the values of the defects; therefore, it had greater importance in the final result of this analysis and was almost fully $(97.14 \%)$ explained by the variables radicle emergence, strong normal seedlings, seedlings with expanded cotyledonary leaves, tetrazolium test results, and potassium leaching (Table 3).
The importance of the tetrazolium test in the variable selection analysis results was noteworthy. It was included in nine equations of sensory evaluation. Figure 1 illustrates the relation of the tetrazolium test with sensory analysis parameters and shows coffee embryos under tetrazolium testing. Lot 9 , with higher sensory quality than that of other lots, had viable embryos; in contrast, the coffee bean embryos from lot 10 were inviable, and the sensory quality of this lot was lower.

An analysis of the selection of physiological variables, seeking to relate them to those of chemical analyses, showed that for the total dependent variables sugars and nonreducing sugars, there were greater coefficients of total determination $\left(\mathrm{r}^{2}\right)$, with values of $90.91 \%$ and $99.94 \%$, respectively. The physiological variables radicle emergence, germination, seedlings with expanded cotyledonary leaves, and tetrazolium were included in the equations of the total variables sugars and nonreducing sugars. For the analysis of reducing sugars and soluble solids, physiological variables that would explain the regression model were not found (Table 4).

Table 3: Analysis of the selection of physiological variables for the sensory analysis of coffee beans at 0 and 3 months of evaluation.

\begin{tabular}{|c|c|c|}
\hline $\begin{array}{l}\text { Dependent } \\
\text { variable }^{1}\end{array}$ & Equation ${ }^{2}$ & $\begin{array}{c}\text { Coefficient of } \\
\text { determination } \\
r^{2}\end{array}$ \\
\hline ARO & $6.24+0.01(49.75 \%)$ REM** & $49.75 \%$ \\
\hline UNI & $6.73+0.03(90.25 \%) \mathrm{TET}^{* *}-0.04(2.08 \%) \mathrm{CON}^{*}+0.04(1.54 \%) \mathrm{POT}^{*}$ & $93.87 \%$ \\
\hline PDE & $\begin{array}{l}7.31+0.01(3.01 \%) \mathrm{REM}^{*}-0.01(3.22 \%) \mathrm{COT}^{* *}+0.02(91.02 \%) \mathrm{TET}^{* *}-0.04(0.61 \%) \\
\text { CON* }^{*} 0.03(0.47 \%) \mathrm{POT}^{*}\end{array}$ & $98.33 \%$ \\
\hline SWE & $\begin{array}{l}7.31+0.01(3.01 \%) \mathrm{REM}^{*}-0.01(3.22 \%) \mathrm{COT}^{* *}+0.02(91.02 \%) \mathrm{TET}^{* *}-0.04(0.61 \%) \\
\text { CON }^{*}+0.03(0.47 \%) \mathrm{POT}^{* *}\end{array}$ & $\%$ \\
\hline FLA & $5.48+0.01(60.97 \%)$ REM$^{* *}+0.02(4.81 \%) \mathrm{SNS}^{*}+0.01(2.67 \%) \mathrm{POT}^{*}$ & $68.46 \%$ \\
\hline $\mathrm{ACl}$ & $6.04+0.01(68.83 \%) \mathrm{TET}^{\star *}$ & $68.83 \%$ \\
\hline BOD & $5.28+0.02(3.59 \%)$ SNS* $^{*} 0.01(6.33 \%) \mathrm{WNS}^{*}+0.01(52.42 \%) \mathrm{TET} * *+0.02(7.06 \%) \mathrm{POT}^{*}$ & $69.41 \%$ \\
\hline AFT & $5.02+0.02(5.74 \%) \mathrm{SNS}^{*}+0.02(51.76 \%) \mathrm{TET}^{* *}+0.01(3.90 \%) \mathrm{CON}^{*}$ & $61.40 \%$ \\
\hline BAL & $5.02+0.02(5.74 \%) \mathrm{SNS}^{*}+0.02(51.76 \%) \mathrm{TET}^{* *}+0.01(3.90 \%) \mathrm{CON} *$ & $61.40 \%$ \\
\hline OVE & $5.51+0.02(9.51 \%)$ SNS* $^{*} 0.01(58.87 \%)$ TET** + $0.01(4.58 \%)$ POT* $^{*}$ & $72.96 \%$ \\
\hline SCO & $\begin{array}{l}46.93+0.17(2.27 \%) \mathrm{REM}^{*}+0.11(0.56 \%) \mathrm{SNS}^{*}-0.05(0.53 \%) \mathrm{COT}^{*}+0.18(91.54 \%) \\
\mathrm{TET}^{* *}+0.13(2.24 \%) \mathrm{POT}^{*}\end{array}$ & $97.14 \%$ \\
\hline \multicolumn{3}{|c|}{ 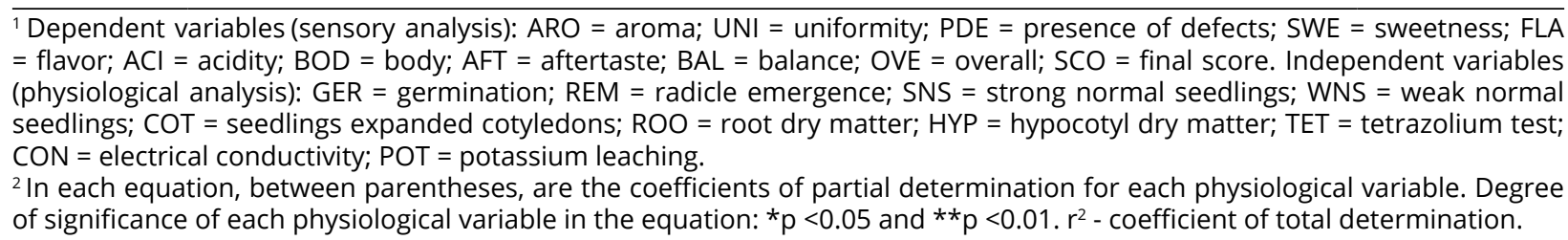 } \\
\hline
\end{tabular}



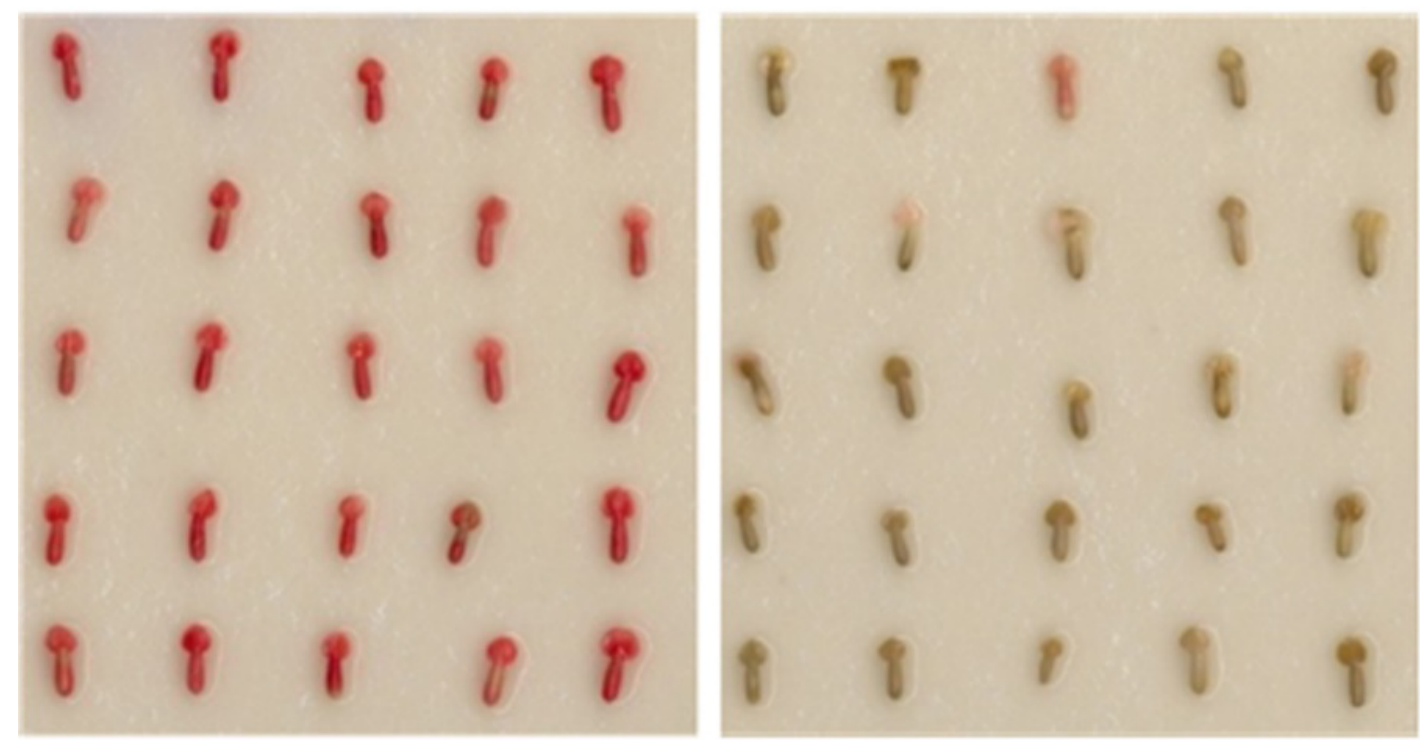

Figure 1: Characterization of Coffea arabica L. embryos of the best quality, Lot 9 (left), and of the worst quality, Lot 10 (right), determined by the viability results of the tetrazolium test.

Table 4: Analysis of the selection of physiological variables for the chemical analyses of coffee beans at 6 months.

\begin{tabular}{|c|c|c|}
\hline $\begin{array}{l}\text { Dependent } \\
\text { variable }^{1}\end{array}$ & Equation $^{2}$ & $\begin{array}{l}\text { Coefficients of } \\
\text { determination } \\
r^{2}\end{array}$ \\
\hline TSU & $\begin{array}{l}8.48+0.03(16.03 \%) \mathrm{REM}^{*}+0.07(30.51 \%) \mathrm{GER}^{*}-0.06(24.90 \%) \mathrm{COT}^{*}-0.04 \\
(19.48 \%) \mathrm{TET}^{*}\end{array}$ & $90.91 \%$ \\
\hline NOR & $\begin{array}{l}7.60+0.06(27.15 \%) \text { REM}^{*}-0.03(22.99 \%) \mathrm{GER}^{*}+0.06(25.49 \%) \mathrm{WNS}^{*}+0.01 \\
(0.64 \%) \mathrm{COT}^{*}-49.84(0.19 \%) \mathrm{ROO}^{*}-0.07(22.61 \%) \text { TET } \\
(0.00(0.87 \%) \text { POT* }\end{array}$ & $99.94 \%$ \\
\hline TAC & $205.98-1.09$ (44.15\%) SNS* & $44.15 \%$ \\
\hline EEX & $12.92-0.01$ (44.24\%) COT* & $44.24 \%$ \\
\hline
\end{tabular}

${ }^{1}$ Dependent variables (chemical analysis): TSU = total sugars; NOR = nonreducing sugars; TAC = titratable acidity; EEX = ether extract. Independent variables (physiological analysis): GER = germination; REM = radicle emergence; SNS = strong normal seedlings; WNS = weak normal seedlings; COT = seedlings expanded cotyledons; ROO = root dry matter; HYP = hypocotyl dry matter; TET = tetrazolium test; $\mathrm{CON}=$ electrical conductivity; $\mathrm{POT}=$ potassium leaching.

2 In the equations, between parentheses, are the coefficients of partial determination. Degree of significance of each physiological variable of the equation: ${ }^{*} p<0.05$ and ${ }^{*} p<0.01 . r^{2}$ - coefficient of total determination.

A canonical correlation analysis of the set of physiological variables determined during the germination test for sensory analysis showed a high coefficient of determination $(95.54 \%)$ by the regression equation of the first canonical pair. Furthermore, the canonical pair was able to differentiate L10 from the others of higher physiological and sensory quality (Figure 2A). In contrast, the second canonical pair of the relation of physiological analyses obtained during the germination and sensory tests did not show a high coefficient of determination and did not allow differentiation of the seed lots (Figure 2B).
The first canonical pair of the relation between the physiological tests that had biochemical principles and the sensory analysis results (Figure 2C) also had a high coefficient of determination $(98.37 \%)$, and the equation allowed differentiation of the lot with the worst physiological and sensory quality, L10 (Figure 2C).

In Figure 2A, on the abscissa axis, labeled "V1", the results of the physiological tests are plotted, and on the ordinate axis, labeled "W1", the results of sensory analyses are plotted. By the regression equation, the coefficient of determination was approximately $96 \%$, 
which is considered high. In addition, the coffee beans show better sensory quality as the physiological quality increases. This same response was found for the first canonical pair.

The three canonical pairs formed by the variables of the physiological tests and those of chemical analyses showed significance $(p<0.0001)$ and a correlation of value of 1 (Figures 2E, 2F, and 2G). However, for the relation between the physiological tests, biochemical principles and the chemical analysis, only the first canonical pair was significant (Figure 2H). Lot 10 (L10), similar to the physiological and sensory analysis findings, showed lower values for the comparison between physiological and chemical analyses in the first canonical pairs (Figures 2E and 2H) than those for other

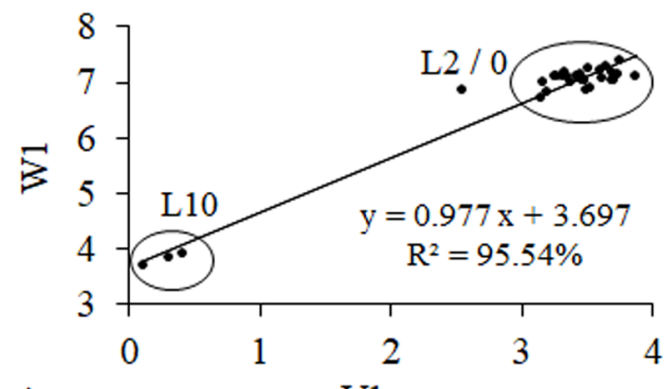

A

V1

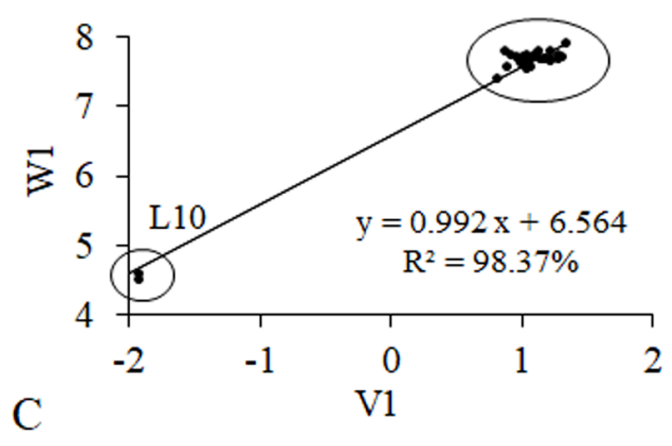

lots. There was also a greater stratification of the lots in the second canonical pair of the physiological variables of the germination test and of the chemical analyses (Figure 2F).

In the first dendrogram of hierarchical cluster analysis, constructed from the results of the sensory and physiological analyses, the aspects evaluated by cuppers (fragrance/aroma, uniformity, absence of defects, sweetness, flavor, acidity, body, aftertaste, balance and overall) showed high similarity and, for that reason, were in a cluster with a distance near zero. The first cluster formed between aspects of the physiological and sensory analysis clustered the sensory measurements of the attributes that composed the final score for hypocotyl and root dry matter (Figure 3A).

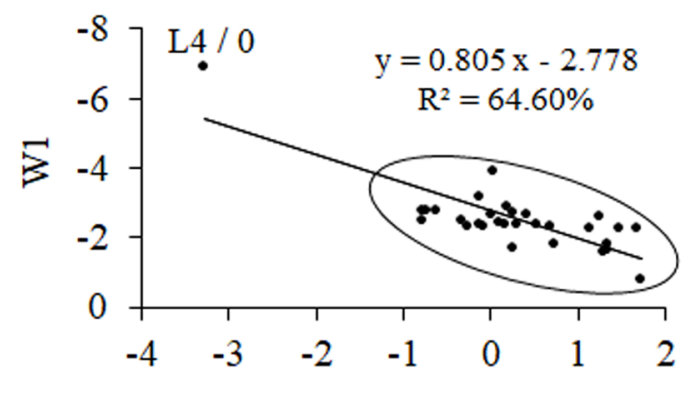

B $\quad$ V1

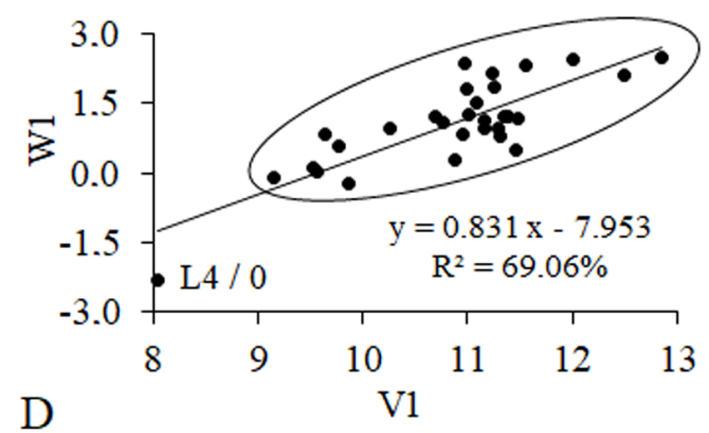

Continue...

Figure 2: Canonical correlations between the physiological tests determined in the germination test (abscissa axis "V1") and sensory analysis (ordinate axis "W1") [first canonical pair - canonical correlation: 0.98 and $p<0.0001(\mathrm{~A})$, and the second canonical pair - canonical correlation: 0.88 and $p<0.004$ (B)]; between the physiological tests with biochemical principles (abscissa axis "V1") and sensory analysis (ordinate axis "W1") [first canonical pair - canonical correlation: 0.99 and $p<0.0001$ (C), and second canonical pair canonical correlation: 0.83 and $p<0.008$ (D)]; between the physiological tests determined in the germination test (abscissa axis "V1") and the chemical analyses (ordinate axis "W1") [first canonical pair - canonical correlation: 1 and $p<0.0001$ (E), and second canonical pair - canonical correlation: 1 and $p<0.0001$ (F), and third canonical pair - canonical correlation: 1 and $p<0.0001(\mathrm{G})]$; and between the physiological tests with biochemical principles (abscissa axis "V1") and chemical analysis (ordinate axis "W1") [first canonical pair canonical correlation: 1 and $p: 0.0018(\mathrm{H})$. 

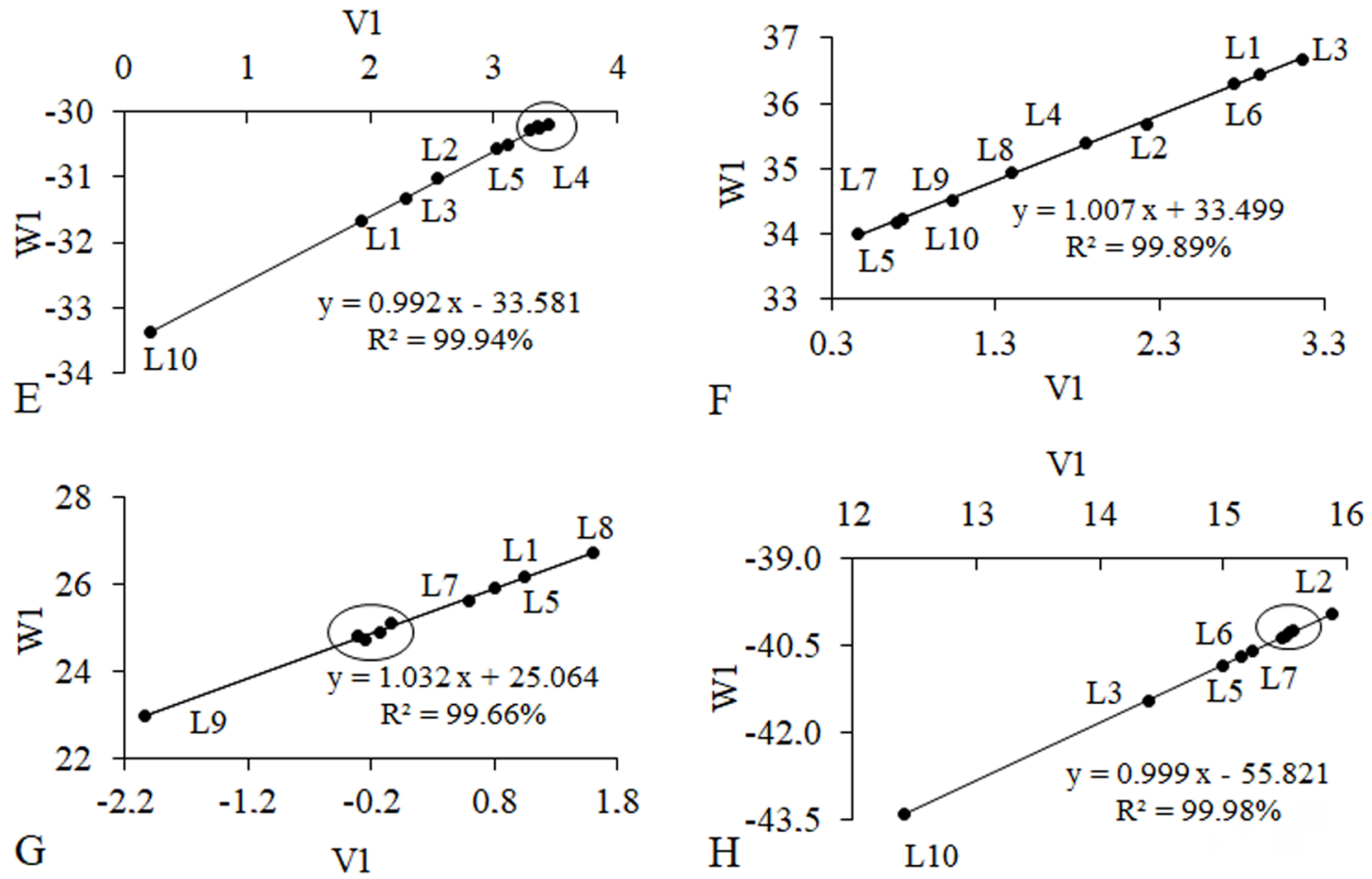

Figure 2: Continuation...
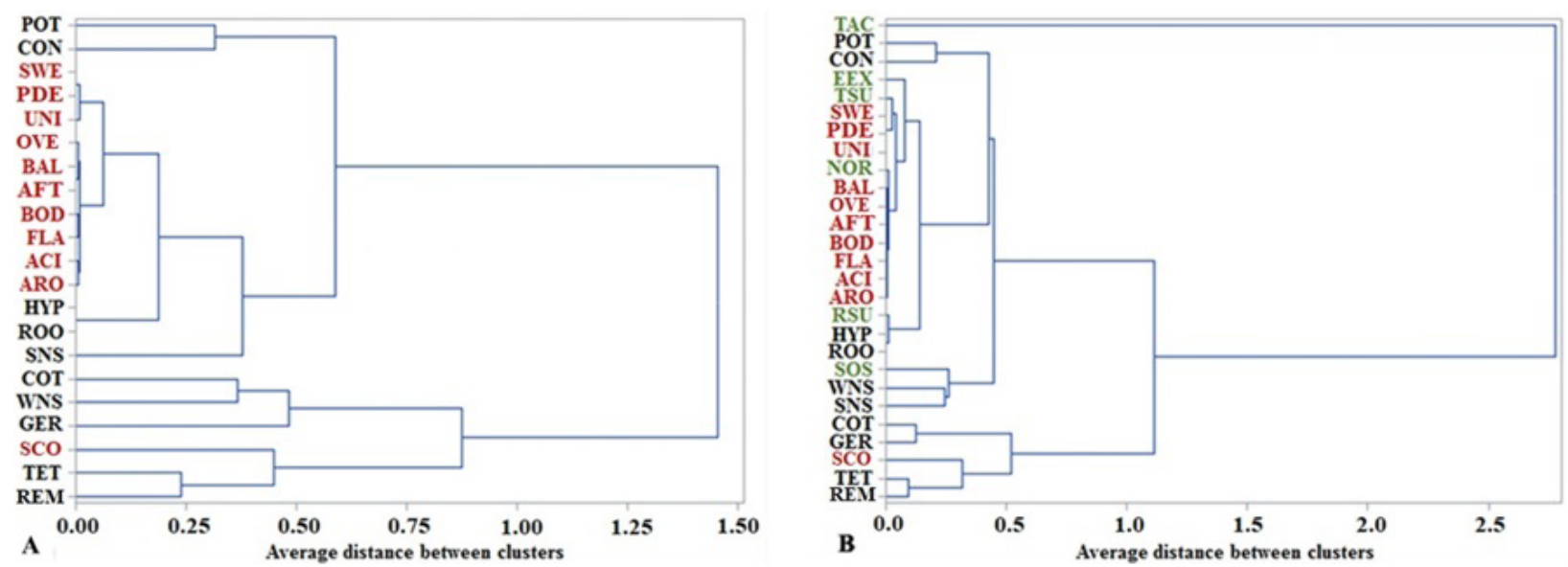

Figure 3: Dendrograms constructed from the results of sensory and physiological analyses of the lots of coffee beans at 0 and 3 months (A) and of the sensory, physiological, and chemical analyses of the lots of coffee beans at 6 months (B).

${ }^{1}$ Sensory analysis: $\mathrm{ARO}=$ aroma; UNI = uniformity; $\mathrm{PDE}=$ presence of defects; SWE = sweetness; $\mathrm{FLA}=\mathrm{flavor} ; \mathrm{ACl}=$ acidity; $\mathrm{BOD}$ = body; $\mathrm{AFT}$ = aftertaste; $\mathrm{BAL}=$ balance; OVE = overall; $\mathrm{SCO}=$ final score. Physiological analysis: GER = germination; REM = radicle emergence; SNS = strong normal seedlings; WNS = weak normal seedlings; COT = seedlings expanded cotyledons; $\mathrm{ROO}$ = root dry matter; HYP = hypocotyl dry matter; TET = tetrazolium test; CON = electrical conductivity; POT = potassium leaching. Chemical analysis: TAC = titratable acidity; TSU = total sugars; RSU = reducing sugars; NOR = nonreducing sugars; SOS = soluble solids; $\mathrm{EEX}=$ ether extract.

${ }^{2}$ Variables of the sensory, physiological, and chemical analyses with letters in red, black, and green, respectively. 
The variable percentage of strong normal seedlings was found with the cluster formed by root and hypocotyl dry matter of coffee seedlings and the attributes of sensory analysis; subsequently, this cluster was with the cluster formed by the variables potassium leaching and electrical conductivity. Although the variables that were of high importance in the models of variable selection did not show greater similarity with the attributes that compose the final score of sensory analysis in cluster evaluation, the most important aspect of sensory analysis, the final score, showed greater similarity to these physiological variables, such as radicle emergence, tetrazolium, germination, weak normal seedlings, and seedlings with cotyledonary leaves (Figure 3A).

In relation to the second dendrogram that included clustering of the sensory, physiological, and chemical variables in the third period of evaluation, the chemical determinations of nonreducing sugars were highly similar to the aspects connected to sensory analysis. The results of the analyses of ethereal extract and total sugars also were highly similar to aspects of sensory evaluation. The analyses of reducing sugars, for their part, exhibited greater similarity to the physiological analyses of root dry matter and hypocotyl dry matter (Figure 3B).

Thus, as in the first dendrogram constructed, the physiological variables of root dry matter and hypocotyl dry matter of seedlings were those that exhibited high similarity to the intermediate aspects of sensory analysis (sweetness, absence of defects, uniformity, balance, overall, aftertaste, body, flavor, acidity, and aroma). However, once more, the final score showed high similarity to aspects of the tetrazolium and radicle emergence test and, after that, to germination and seedlings with expanded cotyledonary leaves (Figure 3B).

However, although the attributes of sensory analysis have a very close relationship with the chemical determinations of total, nonreducing and reducing sugars and ethereal extract, a contradictory aspect was observed in this evaluation, which consists of the fact that the chemical determination of titratable acidity did not exhibit a great similarity to acidity itself from sensory analysis. The titratable acidity variable was clustered with the others at a distance of approximately 2.8 , representing the variable with the least similarity in relation to physiological, sensory, and chemical analyses (Figure 3B).

It is also important to mention that in both cluster analyses, the physiological variables were clustered coinciding with the principle of each test - the percentage of radicle emergence and the tetrazolium test were in the same cluster, the percentage of germination and of seedlings with expanded cotyledonary leaves in another cluster, the determinations of electrical conductivity and potassium leaching in another cluster, and the percentage of weak and strong normal seedlings in a separate cluster (Figures $3 \mathrm{~A}$ and $3 \mathrm{~B}$ ).

The production conditions and the postharvest treatments of coffee beans are responsible for causing modifications in their chemical composition; relevant studies were performed with the aim of determining the effect of the genotype, of the environmental conditions of production, of the forms of processing and of drying the coffee beans, and of their storage on beverage quality (Saath et al., 2014; Borém; Isquierdo; Taveira, 2014; Cheng et al., 2016; Ribeiro et al., 2016; Borém et al., 2019) and on the physiological quality of the seed (Rosa et al., 2011; Taveira et al., 2012; 2015; Santos; Von Pinho; Rosa, 2013). It is a common consensus among researchers that both the sensory quality of the beverage and the physiological quality of the coffee seed are closely related to the chemical composition of the coffee bean and of the coffee seed, respectively.

Taking coffee bean processing as an example, differences in the quality of the coffee beverage coming from coffee beans that went through fermentation are the result of biochemical changes in the low molecular weight components, which are precursors of flavor, such as carbon hydrates (Knopp; Bytof; Selmar, 2006) and free amino acids (Bytof et al., 2005). According to Kleinwächter and Selmar (2010), the components that most change from processing through fermentation of unroasted coffee beans are fructose and glucose, which are important components for attributing quality to the beverage.

The loss of beverage quality of coffee beans that underwent fermentation may be related to the leaching of components during processing and an accentuated consumption of glucose and fructose during the metabolism induced by anoxia (Kleinwächter; Selmar, 2010). Under aerobic conditions, the energy requirements are completely covered by cell respiration. In contrast, under anoxic conditions, sugars (glucose and fructose) are catabolized by fermentation; consequently, a larger amount of sugars is consumed because the yield of energy from fermentation is lower than that of respiration.

A high consumption of sugars affects beverage quality because these components are precursors of the flavor and aroma of the coffee beverage (Bytof et al., 2007; Borém, 2008). Regarding the seeds, physiological quality is changed because these components would be used as a metabolic reserve in supplying energy for the initial growth and development of the coffee seedlings (Callis, 1995; 
Shimizu; Mazzafera, 2000; Waters; Arendt; Moroni, 2017). For example, in a situation of limited reserve components in seeds, seedling vigor may decline. Bytof et al. (2007) added that modifications in the composition of the coffee bean are related to the metabolism during germination that is maintained during processing.

It is notable that adequate practices of production and the postharvest of coffee beans for obtaining materials that will provide a better beverage or superior physiological quality are closely related; i.e., the causes of reduced beverage quality and seed physiological quality are correlated. Consequently, physiological variables, such as those evaluated during the germination test and the tetrazolium test, were associated with sensory analysis variables. These tests reflect the loss of components associated with flavor and aroma (intermediate components that compose the final score of sensory analysis) that are also the energy reserve for seedlings during development.

In addition to processing, drying is a crucial step for maintaining the quality of coffee beans (Saath et al., 2014; Oliveira et al., 2018). In the present study, the use of coffee bean samples coming from three manners of processing and drying, as well as a sample of commercial coffee beans, aimed to obtain materials of different compositions and, in the end, of different physiological and sensory quality. The aim was not to debate these techniques but rather to understand why there is a direct relationship between beverage quality and seed physiological quality.

It is important to emphasize that the reduction in components associated with the energy reserve that will be provided for the seedling during formation is not the only reason associated with the loss of seed physiological quality. In the seed deterioration process, one of the events that occurs and has a large impact on seed physiological quality is the destructuring process of the membrane system. The progress of this event can be monitored through potassium leaching and electrical conductivity tests (Marcos-Filho, 2015).

The principle of the electrical conductivity test consists of the fact that less vigorous materials or more deteriorated seeds show slower speed in membrane repair during water imbibition by the seeds during germination, therefore releasing larger amounts of solutes to the external environment. The loss through leaching includes sugars, amino acids, fatty acids, proteins, enzymes, and inorganic ions $\left(\mathrm{K}^{+}, \mathrm{Ca}^{+2}, \mathrm{Mg}^{+2}, \mathrm{Na}^{+}, \mathrm{Mn}^{+2}\right)$, and the test evaluates the quantity of ions leached (Powell, 1986; Marcos-Filho, 2015). In the case of the potassium leaching test, only the potassium ion $\left(\mathrm{K}^{+}\right)$is evaluated.
Destructuration of the membrane system in seeds causes a reduction in physiological potential because components important for germination are lost (MarcosFilho, 2015). In the case of the coffee beans, damage in their membrane system provides greater contact between the enzymes and the chemical components present in their intra- and extracellular media. These changes lead to chemical reactions that modify the original composition of the coffee, with negative reflections on beverage quality (Coradi et al., 2007; Borém et al., 2008; Saath et al., 2010; Borém et al., 2013a).

The study showed, through the analysis and the selection of variables, that the electrical conductivity and potassium leaching tests are associated with seven equations of sensory analysis variables (Table 3 ). In the cluster analysis, the tests also show a strong relation with the sensory analysis attributes (Figure $3 \mathrm{~A}$ and $3 \mathrm{~B}$ ). These results indicate that the physiological tests of electrical conductivity and potassium leaching can be used as an indication of beverage quality. The results obtained in some studies show the importance of the use of electrical conductivity and potassium leaching as markers of coffee beverage quality (Malta; Pereira; Chagas, 2005; Taveira et al., 2012; Borém et al., 2013b).

As confirmed in this study, analyses of electrical conductivity, potassium leaching, and germination have been used in combination with sensory analysis as indicators of coffee beverage quality. Oliveira et al. (2018) showed that drying coffee beans under high temperature $\left(35 / 50{ }^{\circ} \mathrm{C}\right.$ and $\left.50 / 35^{\circ} \mathrm{C}\right)$ results in simultaneous losses of physiological quality (electrical conductivity, potassium leaching, and germination) and sensory quality of the beverage. Oliveira et al. (2013) also found a direct relationship between physiological and sensory analyses. The same authors showed that coffee beans dried in a drying yard have better sensory and physiological results than beans dried in a mechanical dryer.

The low relation of the titratable acidity variable with the acidity evaluated in the sensory analysis (Figure 3B) can be explained by titratable acidity being related to the occurrence of undesirable fermentations in the coffee beans by the presence of fatty acids. The lower the values of fatty acidity are, the better the quality of the coffee beverage (Oliveira et al., 2013); a larger quantity of free fatty acids is related to greater degradation of the cell membranes (Marques et al., 2008). In contrast, the acidity evaluated by a sensory analysis is related to desirable acidity, indicating the presence of acids that favor beverage flavor, such as malic, citric, and chlorogenic acids, that are part of the composition of 
specialty coffee beans (Ramos et al., 2016; Sunarharuma; Williams; Smyth, 2014).

Coffee beans have a large number of chemical compounds that are subject to modifications, according to production conditions, for example. Due to this diverse composition, it is often not possible to attribute the sensory quality of the beverage to a single analysis or a change in a single component. This concept was raised by Taveira et al. (2014), who identified 44 metabolic markers, such as amino acids, organic acids, carbohydrates, polyols, and other compounds present in the extracts of coffee beans to designate the origin of the product.

\section{CONCLUSIONS}

There is a correlation between physiological quality variables and variables for sensory analysis, confirmed by multivariate analyses of variable selection, canonical correlation, and hierarchical clustering. Greater reliability and speed in the evaluation of coffee quality can be achieved with the combined use of these variables. The viability of coffee embryos in the tetrazolium test has a positive correlation with the final sensory analysis score. There is a correlation of root dry matter, hypocotyl dry matter, potassium leaching, and electrical conductivity with the attributes that constitute the final sensory analysis score of the coffee beans. More studies are necessary to enable the safe use of physiological analyses for the evaluation of coffee beverage quality with the aim of complementing the results of sensory analysis.

\section{ACKNOWLEDGMENTS}

This study was supported by the Foundation for Research Support of Minas Gerais (Fapemig) and the Brazilian Agricultural Research Corporation (Embrapa).

\section{REFERENCES}

ABREU, G. F. et al. Simultaneous optimization of coffee quality variables during storage. Revista Brasileira de Engenharia Agrícola e Ambiental, 21(1):56-60, 2017.

ALVES, T. S.; DIAS, R. C. E.; BENASSI, M. T. Metodologia para análise simultânea de ácido nicotínico, trigonelina, ácido clorogênico e cafeína em café torrado por cromatografia líquida de alta eficiência. Química Nova, 29(6):1164-1168, 2006.

ASSOCIATION OF OFFICIAL ANALYTICAL CHEMISTRY - AOAC. Official methods of analysis of the Association of Official Analytical Chemists. 15th ed. Washington, 1990. 2v.
BORÉM, F. M. et al. Evaluation of the sensory and color quality of coffee beans stored in hermetic packaging. Journal of Stored Products Research, 52:1-6, 2013a.

BORÉM, F. M. et al. Meteorological variables and sensorial quality of coffee in the Mantiqueira region of Minas Gerais. Coffee Science, 14(1):38-47, 2019.

BORÉM, F. M. et al. Microscopia eletrônica de varredura de grãos de café submetidos a diferentes formas de processamento e secagem. Coffee Science, 8(2):227-237, $2013 b$.

BORÉM, F. M. et al. Qualidade do café natural e despolpado após secagem em terreiro e com altas temperaturas. Ciência e Agrotecnologia, 32(5):1609-1615, 2008.

BORÉM, F. M. Processamento do café. In: BORÉM, F. M. Póscolheita do café. Lavras: UFLA, 2008. 631p.

BORÉM, F. M.; ISQUIERDO, E. P.; TAVEIRA, J. H. S. Coffee processing. In: BORÉM, F. Handbook of coffee postharvest technology. Georgia: Gin Press, Norcross, 2014, p.49-68.

BORRÀS, E. et al. Data fusion methodologies for food and beverage authentication and quality assessment - A review. Analytica Chimica Acta, 891:1-14, 2015.

BRASIL. Ministério da Agricultura, Pecuária e Abastecimento. Regras para Análises de Sementes. Ministério da Agricultura, Pecuária e Abastecimento. Secretaria de Defesa Agropecuária. Brasília, DF: Mapa/ACS, 2009. $395 p$.

BYTOF, G. et al. Influence of processing on the generation of $y$-aminobutyric acid in green coffee beans. European Food Research Technology, 220:245-250, 2005.

BYTOF, G. et al. Transient occurrence of seed germination processes during coffee post-harvest treatment. Annals of Botany, 100(1):61-66, 2007.

CALLIS, J. Regulation of Protein degradation. The Plant Cell, 7:845-857, 1995.

CHAMBERS IV, E. et al. Development of a "living" lexicon for descriptive sensory analysis of brewed coffee. Journal of Sensory Studies, 31(6):465-480, 2016.

CHENG, B. et al. Influence of genotype and environment on coffee quality. Trends in Food Science and Technology, 57:20-30. 2016.

CLEMENTE, A. C. S. et al. Operações pós-colheita e qualidade físico-química e sensorial de cafés. Coffee Science, 10(2):233-241, 2015. 
CLEMENTE, A. C. S. et al. Preparo das sementes de café para avaliação da viabilidade pelo teste de tetrazólio. Revista Brasileira de Sementes, 33(1):38-44, 2011.

CORADI, P. C. et al. Effect of drying and storage conditions on the quality of natural and washed coffee. Coffee Science, 2(1):38-47, 2007.

DELLA LUCIA, S. M.; MINIM, V. P. R.; CARNEIRO, J. D. S. Análise sensorial de alimentos. In: MINIM, V. P. R. (Ed.). Análise sensorial: Estudos com consumidores. Viçosa, MG: UFV, 2006. p. 85-109.

DI DONFRANCESCO, B.; GUTIERREZ, N.; CHAMBERS IV, E. Comparison of results from cupping and descriptive sensory analysis of Colombian brewed coffee. Journal of Sensory Studies, 29(4):301-311, 2014.

FARAH, A. et al. Correlation between cup quality and chemical attributes of Brazilian coffee. Food Chemistry, 98(2):373380,2006

FRANCA, A. S.; MENDONÇA, J. C. F.; OLIVEIRA, S. D. Composition of green and roasted coffees of different cup qualities. Food Science and Technology, 38(7):709715, 2005.

INTERNATIONAL ORGANIZATION FOR STANDARDIZATION ISO. Green coffee: Determination of loss mass at $105^{\circ} \mathrm{C}$, Geneva. 2003. 4p.

JOHNSON, R. A.; WICHERN, D. W. Applied multivariate statistical analysis (5th ed.). Upper Saddle River, NJ: Prentice-Hall Inc., 2002. 796p.

KLEINWÄCHTER, M.; SELMAR, D. Influence of drying on the content of sugars in wet processed green Arabica coffees. Food Chemistry, 119:500-504, 2010.

KNOPP, S.; BYTOF, G.; SELMAR, D. Influence of processing on the content of sugars in green Arabica coffee beans. Food Research Technology, 223:195-201, 2006.

LINGLE, T. R. The coffee cupper's handbook: Systematic guide to the sensory evaluation of coffee's flavor. 4th ed. Long Beach: Specialty Coffee Association of America, 2011. 66p.

MALTA, M. R.; PEREIRA, R. G. F. A.; CHAGAS, S. J. de R. Condutividade elétrica e lixiviação de potássio do exsudato de grãos de café: Alguns fatores que podem influenciar essas avaliações. Ciência e Agrotecnologia, 29(5):10151020, 2005.

MANLY, B. J. F. Métodos estatísticos multivariados: Uma introdução. 3.ed. Porto Alegre: Bookman, 2008. 229p.
MARCOS-FILHO, J. Seed vigor testing: An overview of the past, present and future perspective. Scientia Agricola, 72(4):363-374, 2015.

MARQUES, E. R. et al. Eficácia do teste de acidez graxa na avaliação da qualidade do café arábica (Coffea arabica L.) submetidos a diferentes períodos de temperatura e présecagem. Ciência e Agrotecnologia, 32(5):1557-1562, 2008.

NJOMAN, M. F. et al. The vulnerability of human sensory evaluation and the promising senses instrumentation. British Food Journal, 119(10):2145-2160, 2017.

OLIVEIRA, P. D. et al. Aspectos fisiológicos de grãos de café, processados e secados de diferentes métodos, associados à qualidade sensorial. Coffee Science, 8(2):211-220, 2013.

OLIVEIRA, P. D. et al. Quality of natural and pulped coffee as a function of temperature changes during mechanical drying. Coffee Science, 13(4):415-425, 2018.

POWELL, A. A. Cell membranes and seed leachate conductivity in relation to the quality of seed for sowing. Journal of Seed Technology, 10(2):81-100, 1986.

PRAMUDYA, R. C.; SEO, H. Influences of product temperature on emotional responses to, and sensory attributes of, coffee and green tea beverages. Frontiers in Psychology, 8(2264):1-16, 2018

RAMOS, M. F. et al. Discrimination of the sensory quality of the Coffea arabica L. (cv. Yellow Bourbon) produced in different altitudes using decision trees obtained by the CHAID method. Journal of the Science of Food and Agriculture, 96:3543-3551, 2016.

RIBEIRO, D. E. et al. Interaction of genotype, environment and processing in the chemical composition expression and sensorial quality of Arabica coffee. African Journal of Agricultural Research, 11(27):2412-2422, 2016.

RIBEIRO, J. S.; FERREIRA, M. M. C.; SALVA, T. J. G. Chemometric models for the quantitative descriptive sensory analysis of Arabica coffee beverages using near infrared spectroscopy. Talanta, 83(5):1352-1358, 2011.

ROSA, S. D. V. F. et al. The effect of storage conditions on coffee seed and seedling quality. Seed Science and Technology, 39:151-164, 2011.

SAATH, R. et al. Activity of some isoenzymatic systems in stored coffee grains. Ciência e Agrotecnologia, 38(1):15-24, 2014.

SAATH, R. et al. Microscopia eletrônica de varredura do endosperma de café (Coffea arabica L.) durante o processo de secagem. Ciência e Agrotecnologia, 34(1):196-203, 2010. 
SANCHEZ, K.; CHAMBERS IV, E. How does product preparation affect sensory properties? An example with coffee. Journal of Sensory Studies, 30(6):499-511, 2015.

SANTOS, G. C.; VON PINHO, E. V. R.; ROSA, S. D. V. F. Gene expression of coffee seed oxidation and germination processes during drying. Genetics and Molecular Research, 12(4):6968-6982, 2013.

SAS INSTITUTE INC. SAS statistical software, version 9.3. SAS Institute, Inc, Cary, NC, 2010.

SHIMIZU, M. M.; MAZZAFERA, P. Compositional changes of proteins and amino acids in germinating coffee seeds. Brazilian Archives of Biology and Technology, 43(3):259-265, 2000.

SUNARHARUMA, W. B.; WILLIAMS, D. J.; SMYTH, H. E. Complexity of coffee flavor: A compositional and sensory perspective. Food Research International (62):315-325, 2014.

TAVEIRA, J. H. S. et al. Perfis proteicos e desempenho fisiológico de sementes de café submetidas a diferentes métodos de processamento e secagem. Pesquisa Agropecuária Brasileira, 47(10):1511-1517, 2012.

TAVEIRA, J. H. S. et al. Postharvest effects on beverage quality and physiological performance of coffee beans. African Journal of Agricultural Research, 10(12):1457-1466, 2015.

TAVEIRA, J. H. S. et al. Potential markers of coffee genotypes grown in different Brazilian regions: A metabolomics approach. Food Research International, 61:75-82, 2014.

TEKRONY, D. M. Precision is an essential component in seed vigour testing. Seed Science and Technology, 31:435447, 2003.

WATERS, D. M.; ARENDT, E. K.; MORONI, A. V. Overview on the mechanisms of coffee germination and fermentation and their significance for coffee and coffee beverage quality. Critical Reviews in Food Science and Nutrition, 57(2):259-274, 2017. 